\title{
MILOVAN ĐILAS I BRITANSKI LABURISTI 1950-1955.
}

\begin{abstract}
APSTRAKT: Odnos Milovana Đilasa i britanskih laburista, naročito posmatrano kroz prizmu disidentstva, svakako je značajan. Ostvarivanje prvih kontakata, razmenjivanje ideja i stečena prijateljstva doneće i teške političke, kao i lične posledice. U radu je razmatran karakter tih odnosa i uloga britanskih laburista u prvoj fazi disidentstva.
\end{abstract}

Ključne reči: Milovan Đilas, Velika Britanija, Britanska Laburistička partija, disidentstvo

Za „Slučaj Đilas“ britanski laburisti, kao i britanska spoljna politika uopšte, imaju istaknut značaj. Naročito u prelomnim godinama 1950-1955. uticaj laburista na samog Đilasa obeležiće čitavo potonje disidentstvo.

Revolucionarna Jugoslavija, posle SSSR, najintenzivnije odnose imala je upravo sa Britanijom. Stoga je značajno imati na umu dinamiku tih odnosa sa još mladim partizanskim pokretom sve do razdoblja „nesvrstane“ Jugoslavije. Već u izveštaju Ficroja Maklina ${ }^{1}$ uočava se prepoznavanje značaja partizanskog pokreta ali i tendencija ka zbližavanju i pokušaju uvođenja Jugoslavije u zapadnu sferu uticaja, uprkos ideološkim razlikama. ${ }^{2}$ Ipak, prilika je propuštena. Tito se sa Visa, gde je bio pod zaštitom Britanaca, kako Čerčil navodi: „...odjednom izgubio, ne ostavivši adresu, ali zadržavši stražare oko svoje pećine... Tada se uputio u Moskvu“ “. ${ }^{3}$ Nova prilika javila se kao rezultat sukoba sa Informbiroom i Britanija ju je dočekala sa laburističkom vladom na čelu, idealnom za premošćavanje ideološkoj jaza. ${ }^{4}$ Dojučerašnja satanizacija Jugoslavije, u tipično hladnoratovskom maniru,

${ }^{1}$ F. Maklin, Rat na Balkanu, Beograd 1980, 48.

${ }^{2}$ Lj. Dimić, A. Životić, Napukli monolit: Jugoslavija i svet: 1942-1948, Beograd 2012, 63-64 (Izveštaj šefa vojne misije pri Narodnooslobodilačkoj vojsci Jugoslavije brigadira Fitzroya Macleana vrhovnom komandantu savezničkih oružanih snaga na Srednjem istoku generalu Henryju Wilsonu, 6. novembra 1943).

${ }^{3}$ V. Čerčil, Drugi svetski rat, tom 6: Trijumf i tragedija, Beograd 1966, 209.

${ }^{4}$ Uočljivo je, međutim, dvogodišnje oklevanje Velike Britanije (1948-1950) koje je rezultat pre svega uticaja jugoslovenske emigracije, među kojoj se isticao Živko Topalović. 
ustupila je mesto novom pogledu i drugačijoj perspektivi posmatranja u zapadnoj javnosti. U percepciji Đilasa došlo je takođe do zaokreta. Ambasador Stivenson navodi da je upravo Đilas ustanovio jednu od najuticajnijih veza Beograda i Moskve, ${ }^{5}$ misli se, naravno, na period pre 1948. godine. Međutim, nove Đilasove ideje u Britaniji naišle su na podlo tle a sama njegova ličnost svoje zaštitnike.

Sa druge strane jeres Milovana Đilasa i vraćanje partijske knjižice sa brojem $0004^{6}$ duboko je uticala na samu partiju. Šef Agitpropa, ideološki lučonoša 1948. godine ${ }^{7}$, propagirao je nove ideje van, ili nasuprot, partijske linije. Ipak, upravo i iz tih razloga Đilas je bio u mogućnosti da ideološki tumara nadajući se kakvoj promeni. ${ }^{8}$

\section{Britanski laburisti u Jugoslaviji}

Značaj 1948. godine nije promakao Velikoj Britaniji. Za proces zbližavanja sa Zapadom Velika Britanija prestavljala je most kojim bi se prevazišle razlike i antagonizam prema jednoj komunističkoj zemlji. Laburistička vlada Klementa Atlija (1945-1951), bila je savršena za ovu misiju.

Međutim, i u okviru same Laburističke partije tražio se „most“. Prvi pokušaj išao je preko Koni Zilijakusa koji je među britanskim laburistima važio za levo orijentisanog. Ono što je njega naročito izdvajalo, osim boravka u Jugoslaviji 1945. godine, u cilju nadgledanja izbora, jeste drugačiji pogled na komunizam. Zilijakus se zalagao za približavanje Britanije i SSSR a udaljavanje od kapitalističkog Zapada. Osim toga, na Jugoslaviju je gledao pozitivno od samih početaka, zalagao se za njeno priznavanje 1946. godine. $\mathrm{Na}$ području britanske unutrašnje politike pokrenuo je pitanje diktature jedne partije. Sa Titom se sastajao više puta, a često su te posete imale i prijateljsku notu. ${ }^{9}$ Ipak, sami laburisti nisu sa naklonošću gledali na Zilijakusa i njegov uticaj je bio ograničen. ${ }^{10}$

${ }^{5}$ Lj. Dimić, Yugoslav-Soviet Relations: The View of the Western Diplomats (19441946), The Balkans in the Cold War: Balkan Federations, Cominform, Yugoslav-Soviet conflict, edited by V. G. Pavlović, Beograd 2011, 133.

${ }^{6}$ M. Terzić, Preservation of idelogical identity: The normalization of SovietYugoslav relations after Stalin's death, The BALKANS in the Cold War: Balkan Federations, Cominform, Yugoslav-Soviet conflict, edited by V. G. Pavlović, 240.

${ }^{7}$ Isto.

${ }^{8}$ Oslanjajući se na Brodela i Cvijića značajnu ulogu u uzroku disidentstva Dedijer vidi i u „violentnom dinarskom“ mentalitetu Đilasa. On navodi: „Đilas je tipični produkt tog (crnogorskog - N. M.) društva.“ Ključna mentalna nit Crnogoraca, po Dedijerovom mišljenju, jeste mržnja prema državi kao takvoj. Više o tome u: V. Dedijer, Veliki buntovnik Milovan Đilas: prilozi za biografiju, Beograd 1991.

${ }^{9}$ Beograd, Kancelarija maršala Jugoslavije (dalje: KMJ), 836, I-2-a/121, Prijem Britanskog laburističkog poslanika Koni Zilijakusa kod Maršala Tita 09. 1946, I-2-a/128, Prijem 
Do prve posete laburista Jugoslaviji došlo je septembra 1950. godine. To je bila prva zvanična poseta predstavnika jedne socijalističke partije sa Zapada Jugoslaviji, time je imala naročiti značaj. ${ }^{11}$ Sekretar te partije Morgan Filips, predsednik Sem Votson i član izvršnog komiteta Hari Eršon razgovarali su sa vođstvom KPJ ali i putovali po zemlji i tom prilikom obišli i zatvor u Sremskoj Mitrovici. Na zvaničnom sastanku, pored Tita, bili su prisutni Kidrič, Đilas i Dedijer (kao prevodilac). Razgovori su protekli u izrazito prijateljskom tonu i doprineli su zbližavanju. ${ }^{12} \mathrm{U}$ izveštaju rukovodstvu laburističke partije Votson će idealizovati političko stanje u Jugoslaviji. ${ }^{13}$ Veliku pažnju privuklo je i samoupravljanje čije je osnove delegaciji predočio Tito ali i Đilas. Sam Đilas razgovore je okarakterisao kao „otvorene i zbližujuće“. ${ }^{14}$

Pored hvala i očiglednog interesovanja razlike nisu prošle nezapaženo. U poverljivom izveštaju o poseti Jugoslaviji Morgan Filips navodi da su Tito i vrh partije 100\% komunisti i da bi bilo šta drugo predstavljalo zabludu. Režim i samu državu okarakterisao je kao „policijsku“. ${ }^{15}$ Ipak, spoljnopolitički interesi su prevladali razlike i ekonomska pomoć je osigurana. Da su se pretpostavke o laburistima kao o „mostu ka Zapadu“ pokazale tačnim pokazuje podatak da je ubrzo posle ove posete Bevan izvršio odlučujući pritisak na SAD u pitanju pomoći Jugoslaviji. ${ }^{16}$

\section{Milovan Đilas u Velikoj Britaniji}

U kompleksnom spoljnopolitičkom položaju, pred sve većom pretnjom eventualnog Staljinovog napada na Jugoslaviju, Đilas u pratnji Vladimira Dedijera posećuje Veliku Britaniju 1951. godine. Poseta je pored diplomatske važnosti imala i uticaj na samog Đilasa, pre svega usled prisnijeg kontakta sa laburistima, i bila je ključna za razvijanje potonjih odnosa $u$ disidentstvu.

člana Britanskog parlamenta Koni Zilijakusa kod Maršala Tita 4. septembar 1949, I-2-a/130, Prijem bivšeg poslanika britanskog parlamenta Koni Zilijakusa kod Maršala Tita 3. jun 1950, I-2-a/139, Prijem britanskog javnog radnika Koni Zilijakusa sa suprugom kod Maršala Tita 27. septembar 1951.

${ }^{10} \mathrm{KMJ}, 836$, I-3-b/943, Zabeleška o razgovoru pomoćnika ministra inostr. poslova Matesa sa g. Peak, ambasadorom Engleske, 12. oktobra 1950. u 12 časova: Depeša Dedijera Zilijakusu.

${ }^{11} \mathrm{KMJ}, 836$, I-2-a/140, Prijem predsednika i ministra inostranih poslova vlade Velike Britanije Entoni Idna kod Maršala Tita, Beograd, Bled 18-22. septembar 1952.

${ }^{12}$ KMJ, 836, I-2-a/133, Prijem delegacije laburističke stranke Velike Britanije predsednika Sama Votsnona, sekretara Morgana Filipsa i člana izvršnog komiteta Hari Eršona, Beograd 18. septembar 1950.

${ }^{13}$ Č. Štrbac, Svedočanstva o 1948, Beograd 1989, 113.

${ }^{14}$ M. Đilas, Vlast, London 1983, 215.

15 Č. Štrbac, Svedočanstva o 1948, 116.

${ }^{16}$ Isto, 117. 
Cilj posete bio je da se od Velike Britanije dobije podrška u vidu vojne opreme usled nejasne Staljinove politike prema Jugoslaviji. Titovim rečima rečeno: „... sondiranje terena radi dobijanja naoružanja za našu Armiju“. ${ }^{17}$ Kao svojevrsni most između komunista i Zapada, laburisti su predstavljali polaznu tačku za dalje zbližavanje: „....jer naša je glavna namjera da se mi čim više povežemo u inostranstvu sa onim radničkim i naprednim organizacijama na koje mi možemo imati najviše uticaja sa našom praksom, a tu, razumije se dolazi u prvom redu Laburistička partija u obzir" ${ }^{18}$

Odmah po dolasku u London ističe se da je kontakt sa tadašnjim predsednikom vlade Atlijem ostvaren preko Bevana, tada ministra zdravlja $\mathrm{u}$ Atlijevoj vladi ${ }^{19} \mathrm{i}$ njegove supruge, takođe istaknute laburistkinje Dženi Li, sa kojima se sastao Dedijer. Kao vođa levih laburista „bevanovca“ predstavljao je savršenu polaznu tačku za probijanje leda. Usled bolesti, međutim, umesto Bevana delegaciju je primio njegov zamenik Ernest Dejvis. ${ }^{20}$ Ipak za ključni sastanak sa Atlijem, 31. januara 1951. godine, odgovoran je Bevan. Sam sastanak, ako se sagleda broj učesnika: Đilas, Atli i Dedijer (kao prevodilac), imao je i tajan, ali time i konkretan karakter. ${ }^{21}$ Na sastanku Đilas je izneo Titove zahteve ali i uverenje da će u slučaju Staljinovog napada na Zapadnu Evropu Jugoslavija stati uz zapadne saveznike. Istakao je da je vojna pomoć već tražena i u SAD i da je prijem zahteva bio pozitivan, u šta je Atli sumnjao. ${ }^{22}$ Zanimljiva je i Đilasova izjava, u kontekstu kasnijeg dolaska konzervativaca na vlast: „Naše srce je kod laburista, a mozak mora voditi računa o konzervativcima“. ${ }^{23}$

Da je sastanak sa Atlijem bio ključan i da je na njemu, manje-više, sve dogovoreno, pokazuje i sledeći susret sa Atlijem, na ručku, gde je bilo prisutno još nekoliko ministara laburističke vlade, uključujući i Bevana. Sam ručak imao je neformalan karakter i protekao je u šali i pričanju viceva. ${ }^{24}$ Tom prilikom Đilas se upoznao sa Bevanom koga je kasnije okarakterisao kao „dinamičnu ličnost, živog, nekonvencionalnog uma“25.

Pored sastanka sa laburistima u Kraljevskom institutu za međunarodne odnose Đilas je održao predavanje o jugoslovenskom-sovjetskim odnosima. Posle predavanja priređen je i ručak za „Njegovu ekselenciju Milovana Đilasa“ od strane domaćina general-majora ser Jana Džekoba.

\footnotetext{
${ }^{17}$ Titov dnevnik, priredio P. Simić; stručni saradnik N. Pantelić, Beograd 2009, 90.

${ }^{18}$ Isto, 94.

${ }^{19}$ S. Clissold, Djilas: The progress of a revolutionary, London 1983, 219.

${ }^{20}$ M. Đilas, Vlast, 216.

${ }^{21}$ V. Dedijer, Veliki buntovnik Milovan Đilas: prilozi za biografiju, 360.

${ }^{22}$ I. Laković, Zapadna vojna pomoć Jugoslaviji: 1951-1958, Podgorica 2006, 40.

${ }^{23}$ AJ, KMJ I-3-b/ 948; Navedeno prema: Titov dnevnik, 174.

${ }^{24}$ V. Dedijer, Veliki buntovnik Milovan Đilas: prilozi za biografiju, 364.

${ }^{25}$ M. Đilas, Vlast, 216.
} 
Samo Đilasovo predavanje bilo je odlično pripremljeno i naišlo je pozitivan prijem među slušaocima, što ipak nije za iznenađenje jer je antisovjetizam bio izražen kako u predavanju tako i u stavovima slušalaca. ${ }^{26}$ Zanimljivo je i pisanje britanske štampe o samom Đilasu: Observer (The Observer) 4. februara 1951. navodi da su stavovi izlagača sličniji „preboljševičkim marksistima" nego lenjinistima. ${ }^{27}$

Đilas i Dedijer su imali i jednu posetu privatnog karaktera, ali svakako od državničkog značaja. U pitanju je poseta Vinstonu Čerčilu, koja je imala izrazito neformalan karakter ali je predstavljala prvi susret „partizana" sa Čerčilom od sukoba oko Trsta 1945. godine. ${ }^{28}$

Sam cilj posete bio je ostvaren: „Britanska vlada gleda sa simpatijom naše traženje pomoći u oružju“29 - glasila je Atlijeva konstatacija. Jugoslavija je našla čvrst oslonac $u$ međunarodnim odnosima i mogla je nastaviti svoj put u komunizam omogućen - paradoksalno - pomoći kapitalističkog Zapada. Ipak, poseta Britaniji imala je značaj i za samog Đilasa i svakako uticala na disidentstvo. U svojim beleškama ${ }^{30}$ i Dedijer i Đilas primećuju osrednjost Čerčilove kuće i njenu skromnost u odnosu na dedinjske vile u koje su se uselili visoki funkcioneri KPJ, pa i Đilas.

Reakcija domaćina bila je veoma pozitivna. Rukovodstvo laburističke partije bilo je impresionirano Đilasom, pa i sam Atli. ${ }^{31}$ Stari saborac Fricroj Maklin u pismu ambasadoru Velike Britanije Čarlsu Piku piše: „Sve u svemu on (Đilas - N. M.) je ostavio odličan utisak i imam osećaj da je ovaj neposredni kontakt mnogo učinio za razbijanje sumnje mnogih konzervativaca u vezi Titovog režima“. ${ }^{2}$

Pri povratku iz Londona Đilas i Dedijer kratko su se zadržali u Parizu. Za našu temu je značajan razgovor između Đilasa i američkog novinara Sulcbergera. Svoju ulogu prevodioca u tom razgovoru Dedijer je prekoračio i poverio američkom kolegi da je Đilas veoma impresioniran Velikom Britanijom, naročito njihovim sindikatima koje je smatrao daleko manje birokratizovanim nego jugoslovenskim. ${ }^{33}$

Sama poseta nije prošla nezapaženo i u službama SAD. Američki ambasador u Beogradu Alen izveštava da postoji sumnja kako se Đilas i

${ }^{26}$ V. Dedijer, Veliki buntovnik Milovan Đilas: prilozi za biografiju, 363.

${ }^{27}$ D. Tošić, Ko je Milovan Đilas?: disidentstvo 1953-1995, Beograd 28.

${ }^{28}$ V. Dedijer, Veliki buntovnik Milovan Đilas: prilozi za biografiju, 362.

${ }^{29}$ M. Đilas, Vlast, 216. grafiju, 362.

${ }^{30}$ M. Đilas, Vlast, 216; V. Dedijer, Veliki buntovnik Milovan Đilas: prilozi za bio-

${ }^{31}$ KMJ, 836, I-2-b/948, Izveštaji i telegrami ambasadora u Londonu Jože Brileja i otpravnika poslova Branka Zlatarića - Ministarstvu inostranih poslova.

${ }_{32}$ KMJ, 836, I-2-b/948, Pismo Ficroj Meklejna Čarlsu Piku 31. januar 1951.

${ }^{33}$ D. Bekić, Jugoslavija u hladnom ratu: Odnosi sa velikim silama 1949-1955, Zagreb $1988,251$. 
Dedijer mimo znanja britanske vlade sastaju sa krajnje levim članovima laburističke partije. Zanimljiva je njegovo konstatacija: „Svrstavam ih među najzloćudnije figure sadašnjeg režima, iako se Đilas trudio da me uveri kako on usmeruje KPJ prema zapadnoj orijentaciji“. ${ }^{34}$

Ubrzo posle povratka u Beograd u samoj Britaniji je usledila promena vlasti i na čelo je došla konzervativna vlada predvođena Vinstonom Čerčilom (1951-1955). Izvesno ohlađenje odnosa bilo je vidljivo u odnosu prema jugoslovenskoj političkoj emigraciji, koja je sada dobila podršku od strane vlade. ${ }^{35}$ Ipak, kontakti sa laburistima nisu jenjavali. Svoj odmor Bevan i Džen Li, na poziv Dedijera (što je bila Đilasova ideja uz Titovo odobrenje), odlučili su da provedu u Jugoslaviji. U pratnji Đilasa posetili su prestonicu ali i, na sopstveni zahtev, ruralne krajeve Crne Gore. ${ }^{36} \mathrm{O}$ bliskosti gostiju i domaćina pokazuje i podatak da je tom prilikom Đilas na Biogradskom jezeru gatao u plećku predviđajući budućnost svojim gostima. ${ }^{37}$ Osim toga gosti su bili smešteni u vili koja je pripadala Đilasu, on i supruga Štefica ustupili su im svoju spavaću sobu. ${ }^{38}$ Gotovo 30 godina kasnije Dženi Li u knjizi Moj život sa Najom napisala je o domaćinu: „Milovan Đilas, zamenik predsednika vlade i naš domaćin, ostavio je na nas utisak da, kao što je ranije žestoko ispoljavao odanost Staljinu, tako sada pada u opasnost preteranog hvaljenja dobrih strana Zapadnog sveta“39. Sa druge strane Bevan navodi da je bio očaran Titovom „veličinom" ali i ističe naročitu bliskost u odnosu sa Đilasom. ${ }^{40}$ Značajno je da je tom prilikom ukazao i na sličnost ideja: „Može se zaključiti da - u različitim državama, pod različitim okolnostima - identična ili slična gledišta se rađaju“. ${ }^{41}$

Iako je privatnog karaktera, poseta ona nije ostala bez političkih posledica. Laburistička partija bila je nezadovoljna posetom budući da su je konzervativci obilato koristili u izbornoj kampanji, u negativnom kontekstu svakako. Sam Bevan je napadan kao „Tito od Tonypandy-a“42. Bevan se,

${ }^{34}$ FRUS/1951/Vol. IV/pp. 1713-14/Note 2, Navedeno prema: D. Bekić, Jugoslavija u hladnom ratu: Odnosi sa velikim silama 1949-1955, 250.

${ }^{35}$ KMJ, 836, I-2-a/140, Prijem predsednika i ministra inostranih poslova vlade Velike Britanije Entoni Idna kod Maršala Tita, Beograd, Bled 18-22. septembar 1952.

${ }^{36}$ V. Dedijer, Veliki buntovnik Milovan Đilas: prilozi za biografiju, 373.

${ }^{37}$ Isto, 103.

${ }^{38}$ M. Đilas, Vlast, 254.

${ }^{39}$ Dž. Li, Moj život sa Najom, London, 1980, 194. Navedeno prema V. Dedijer, Veliki buntovnik Milovan Đilas: prilozi za biografiju, 14.

${ }^{40}$ Michael Foot, Aneruin Bevan, Vol. 2, 347; Navedeno prema: S. Clissold, Djilas: The progress of a revolutionary, 220.

${ }^{41}$ Isto, 221.

${ }^{42}$ Naziv se odnosi na radničke nerede u gradu Tonipandiju 1910-1911. u čijim je surovim gušenjima istaknutu ulogu imao sam Čerčil. U redovima radnika bilo je i komunista. 
doduše, na ove napade nije naročito obazirao i njegovi odnosi prema Đilasu i Titu ostali si nepromenjeni. ${ }^{43}$

Sa novom vladom Britanije Tito je takođe ostvario prisne odnose. Kao prvi zapadni državnik visokog ranga Entoni Idn posetio je Jugoslaviju septembra 1952. godine. Tito je posetu uzvratio marta 1953. i naišao na srdačan prijem. Poseta je, po pisanju Njujork tajmsa (The New York Times), pokazala da je moguća saradnja između „zapadnih demokratija i komunizma". ${ }^{44}$

Đilas je 1. juna 1953. ponovo posetio Britaniju, ovog puta povodom krunisanja kraljice Elizabete II. U jugoslovenskoj delegaciji su i ministar spoljnih poslova Koča Popović i načelnik generalštaba Peko Dapčević. ${ }^{45}$ Sama poseta nije ostavila dublji trag i imala je pretežno protokolaran karakter.

Sagledavajući odnose sa Britanijom posle 1948. godine do „Slučaja Đilas" može se uočiti da je "most ka Zapadu“, koji je predstavljala laburistička vlada Klementa Atlija, uspešno premošćen. Saradnja je ostvarena na ekonomskom, vojnom i diplomatskom polju. Ipak na polju ideologije i dalje je postojao jaz između demokratije (anglosaksonskog tipa) i „100\%“ jugoslovenskih komunista. Đilas se odlučio za smanjenje tog jaza, ali se pokazalo da je u tome ostao usamljen.

\section{Britanski laburisti i slučaj Đilas 1953-1955.}

Prvim člankom u „Borbi“ Nove sadržine ${ }^{46}$ 11. oktobra 1953. klupko je počelo da se odmotava. Milovan Đilas, dugogodišnji član Politbiroa, jedan od prvih ljudi u vlasti, krenuo je na put disidentstva na kome će i ostati gotovo čitavog života. Na tom putu imaće pouzdane saveznike - britanske laburiste.

Već prilikom sagledavanja uzroka koji su doveli do sudbonosnih 18 članaka ${ }^{47}$ uočava se uticaj laburista. Laburisti su vršili pritisak usmeren na promenu režima u Jugoslaviji, što pokazuje i izjava Klementa Atlija na konferenciji za štampu 18. avgusta 1953: „U Jugoslaviji neće biti pune demokratije ako se ne dozvoli otvorena opozicija političkih stranaka“48. ${ }^{40}$ kritike

${ }^{43}$ KMJ, 836, I-2-a/140, Prijem predsednika i ministra inostranih poslova vlade Velike Britanije Entoni Idna kod Maršala Tita, Beograd, Bled 18-22. 09. 1952.

${ }^{44}$ Č. Štrbac, Svedočanstva o 1948, 99.

${ }^{45}$ M. Đilas, Vlast, 251.

${ }^{46}$ M. Đilas, Pad nove klase: povest o samorazaranju komunizma, Beograd 1994, 147.

${ }^{47}$ Različiti su navodi o broju članaka, sam Đilas navodi 18 (M. Đilas, Vlast, 259), dok se u literaturi može naći i broj od 20 članaka.

${ }^{48}$ Beograd, Arhiv Predsednika Republike (APR), Kabinet Predsednika Republike (KPR) II-4-a/1, Materijal za polemiku o našij demokratiji sa informacijom o nekim slabostima u radu organa radničkog samoupravljanja. 
demokratije u Jugoslaviji sam Tito je često odgovarao stavljanjem akcenta na lične slobode, međutim, na pitanje da li je zadovoljan ličnim slobodama u Jugoslaviji Atli je odgovorio: „Jesam, ja sam ih video i hoću da ih vidim dopunjene slobodom obrazovanja političkih stranaka koje će se nadmetati na stranačkim izborima“. ${ }^{49}$ Upravo se za pluralizam zalagao Đilas u svojim člancima.

Sa razumevanje disidentstva i odnosa laburista prema Đilasu potrebno je i sagledati osnovna načela Laburističke partije. U njenom temelju stoji upravo idejni i politički pluralizam. ${ }^{50}$ Međutim, za razumevanje reakcija na slučaj Đilas među jugoslovenskim komunistima značajno je to što laburisti odbacuju marksističku teoriju i klasnu borbu a zalažu se za postepene društvene promene. ${ }^{51}$

Sa druge strane zanimljiva je teza, naročito u kontekstu uloge laburista, o eventualnoj borbi za vlast koji pominje Dedijer a donekle i sam Đilas. Posle Tita, Đilas je bio najpopularniji član Politbiroa. Dedijer beleži i izjavu Kardelja da je Đilasov san bio da svrgne Tita. ${ }^{52}$ Pored toga navodi i njegovu izjavu: „Treba ići postepeno. Kroz šest meseci bi trebalo da počnu prve demonstracije“ ${ }^{53}$. Ističe se i prisniji odnos sa crnogorskim generalima uoči plenuma $1954 .{ }^{54}$ Činjenica je, međutim, da su najveće optužbe na samom plenumu potekle upravo sa crnogorske strane. I sovjetski obaveštajci su primetili da u toku Đilasovog uklanjanja „mnogi su u Jugoslaviji očekivali puč“. ${ }^{55}$ Sudbonosne 1953. godine desio se niz događaja koji su njegovu slavu utvrdili a možda i preuveličali. Na demonstracijama u Beogradu oko Tršćanske krize Đilas se našao među demonstrantima koji su ga euforično pozdravili i nosili na rukama kao heroja. ${ }^{56}$ Potom, na kongresu uoči proslave 35-godišnjice Ruske revolucije održao je govor koji je izazvao oduševljenje među prisutnima. Sam Titov govor prošao je manje zapaženo. U svojim memoarima Đilas daje nagoveštaj o svome značaju tada: „I moja majka je slušala u Beogradu, sa mojom suprugom, prenos Kongresa. Iz moje majke je, kad se huka izazvana tim mojim istupanjem stišala, progovorilo

${ }^{49}$ APR, KPR, II-a/1, Materijal za polemiku o našij demokratiji sa informacijom o nekim slabostima u radu organa radničkog samoupravljanja.

${ }^{50}$ V. Vasović, Savremene demokratije, Tom I, 422.

${ }^{51}$ Isto, 421.

${ }^{52}$ V. Dedijer, Veliki buntovnik Milovan Đilas: prilozi za biografiju, 398.

${ }^{53}$ Isto, 331; Još u toku rata u Crnoj Gori, među narodom, bila je prisutna parola: „Crna Gora stalno pita kad će Đilas mesto Tita“; M. Terzić, Titova vještina vladanja: Maršal i Maršalat: 1943-1953, Podgorica 2005, 46

${ }^{54}$ V. Dedijer, Veliki buntovnik Milovan Đilas: prilozi za biografiju, 331-332.

${ }^{55}$ A. Edemskii, The role of Milovan Đilas in Soviet-Yugoslav relations, 1944-1954, The Balkans in the Cold War: Balkan Federations, Cominform, Yugoslav-Soviet conflict, 218.

${ }^{56}$ V. Dedijer, Veliki buntovnik Milovan Đilas: prilozi za biografiju, 415. 
drevno, još uvek živo iskustvo: Nije to dobro za Đida kad mu pljeskaju više no Titu“ ${ }^{57}$ Ipak potvrdu ovoga nailazimo i kod Dedijera: „Auditorijum je euforično vikao. I Tita su pozdravljali oduševljeno, ali su mnogo više klicali Đilasu, a to se Titu nije svidelo“. ${ }^{58}$ Zanimljivo je da kao i svedoka imamo istoričara Venceslava Glišića: „... šesti kongres KPJ, u novembru 1952. godine, na kome je Đilas briljirao tako da je pomalo zasenio i Tita". ${ }^{59}$ No svakako značajniji momenat došao je opet sa zapadne strane. U Njujork tajmsu 24. novembra 1953. objavljeno je da je na izborima, naravno bez stvarne opozicije, Tito bio drugi iza Đilasa, to jest da je Đilas dobio veći procenat glasova. ${ }^{60}$ Sa druge strane veliku pažnju privukao je i u Trećem svetu, prilikom posete Indiji, Burmi, Pakistanu. U svojim memoarima o ovom putovanju navodi: „Ali na mene je, rekao bih, to azijsko putovanje ostavilo dublji, neprolazniji utisak". ${ }^{61}$

Značaj je i kompleksan odnos Đilasa i SSSR-a. Njegova uloga ideološkog ratnika u sukobu sa Informbiroom ostavila je posledice. Naime, u eventualnoj normalizaciji odnosa Jugoslavije i SSSR-a sudbina Đilasa bila bi zapečaćena. Svoje stav izneo je i javno, na govoru u Titogradu, ocenivši da su navodi onih koji govore o vraćanju odnosa na pre 1948. godinu „smešni“. ${ }^{62}$ U takvoj situaciji Zapad je za samog Đilasa predstavljao slamku koju ni po koju cenu nije smeo da ispusti.

Članci su ubrzo privukli pažnju i u Savezu komunista se povela rasprava. Naročito upečatljiv bio je članak Anatomija jednog morala. ${ }^{63}$ Ključno je međutim bilo nastojanje izraženo u člancima za formiranje još jedne opozicione partije, a daljom razradom i preobražavanje samog komunističkog režima u socijaldemokratski. U razgovoru sa Kardeljem Đilas je navodno direktno predložio stvaranje laburističke partije u Jugoslaviji. ${ }^{64}$ Nazad se nije moglo i ubrzo je sazvan Treći vanredni plenum SK SKJ.

Još pre sazivanja Plenuma članci nisu prošli neopaženo ni kod britanske diplomatije. U izveštaju britanske ambasade 15. januara 1954. navodi se da je Đilas u člancima izneo socijaldemokratske ideje. Osim toga najveću pažnji privukla je upravo Anatomija jednog morala. ${ }^{65}$

${ }^{57}$ M. Đilas, Vlast, 231.

${ }^{58}$ V. Dedijer, Veliki buntovnik Milovan Đilas: prilozi za biografiju, 398.

${ }^{59}$ V. Glišić, Istoričarevi susreti i razgovori sa Milovanom Đilasom, Tokovi istorije, 12, 2002, 104.

${ }^{60}$ V. Dedijer, Veliki buntovnik Milovan Đilas: prilozi za biografiju, 416-417.

${ }^{61}$ M. Đilas, Vlast, 243.

${ }^{62}$ A. Edemskii, The role of Milovan Đilas in Soviet-Yugoslav relations, 1944-1954, The Balkans in the Cold War: Balkan Federations, Cominform, Yugoslav-Soviet conflict, 204-205.

${ }^{63} \mathrm{M}$. Đilas, Pad nove klase: povest o samorazaranju komunizma, 171.

${ }^{64}$ V. Dedijer, Veliki buntovnik Milovan Đilas: prilozi za biografiju, 377.

${ }^{65}$ Yugoslavia: Political Diaries 1918-1965, Vol. 4: 1949-1965, Edited by, R. L. Jarman, Archive Editions, Oxford, 1997, 527-528. 
Na samom plenumu, januara 1954, tema je bila jedna: Milovan Đilas. Izlagačima na plenumu nije promakao značaj Đilasa $u$ inostranstvu. Sam Tito u svome izlaganju navodi: „... da i ne govorim o onoj reakciji na Zapadu koja smatra da on nosi zastavu naše partije“. ${ }^{66} \mathrm{U}$ izlaganju Aleša Bebler primećuje se da je mogući uzrok poseta Indiji i značaj koji mu je pridavan "Verovatno u Engleskoj ... ja mislim da si se opio od toga Đido“. Zatim navodi: „ti si za zapadnu reakciju predstavnik „slobodarskih tendencija“ a mi svi „diktatorskih tendencija““ “ ${ }^{67}$ Slično zapažanje imao je i Petar Stambolić koji, pozivajući se na „riječi radnika-komunista“, smatra da Đilasa nije trebalo pustiti u inostranstvo, da je pao "pod uticaj Bevana“ ${ }^{68}$ Isto zapažanje Stambolića Dedijer prenosi ogoljeno i direktnije: „Zatim su iznete otvorene optužbe da je Naj Bevan socijal-demokratska hulja, odgovoran za odvajanje Đilasa od komunizma i uvlačenja u socijal-demokratsku revizionističku klopku“. ${ }^{69}$ Sami članci su osuđeni, Đilas je isključen iz CK i smenjen sa svih partijskih i državnih funkcija. Zapisnici sa plenuma u celosti su preneseni u Borbi i Politici. ${ }^{70}$ Usled javnost plenuma ni laburistima nije promaklo njihovo dovođenje u vezu sa slučajem.

Nekoliko dana posle plenuma, 1. februara iste godine, Tito je dobio pismo od Bevana u kome izražava zabrinutost kako za Đilasa tako i za Dedijera. Zanimljivo je da mu zapažanja o njihovoj povezanosti nisu promakla: „Iz nekih primedaba proteklih od ljudi iz Vaše zemlje, koji se nalaze na visokim položajima, shvatio sam da se smatra da je pod mojim lošim uticajem Milovan formirao svoj politički stav, i da je naše prijateljstvo uticalo na njegovo ponašanje“" ${ }^{\text {“11 }}$. Takođe veoma direktno poručuje: „Ništa me drugo ne interesuje osim dobrobiti Vlade (Dedijera - N. M.), Milovana i njihovih porodica“72. U odgovoru Tito uverava Bevana da smatra da nije on uticao na Đilasa kao i da lična sloboda Đilasa neće biti ugrožena. ${ }^{73}$ Uključila se i Dženi Li: prilikom razgovora sa sekretarom Kneževićem u Donjem domu izrazila je čuđenje u odnosu na nagli zaokret u kontekstu odnosa sa Zapadom. Sam „Slučaj Đilas" videla je kao obračun sa nosiocima progresa i demokratije a koji je pružio satisfakciju SSSR. ${ }^{74}$

${ }^{66}$ APR, Plenarne sednice CK KPJ 1948-1978 II/11, Izlaganje Tita na Trećem plenumu.

${ }^{67}$ APR, Plen. sed. CK KPJ 1948-1978 II/11, Izlaganje Aleša Beblera na Trećem plenumu.

${ }^{68}$ B. Kovačević, Đilas heroj - antiheroj: iskazi za istoriju, 475

${ }^{69}$ V. Dedijer, Veliki buntovnik Milovan Đilas: prilozi za biografiju, 406.

${ }^{70}$ Borba, 18. januar 1954, 1-6; Borba, 19. januar 1954, 1-7; Borba, 20. januar 1954, 1-3; Politika 28. januar 1954, 2-8; Politika, 19. januar 1954, 1-10.

${ }^{71}$ V. Dedijer, Veliki buntovnik Milovan Đilas: prilozi za biografiju, 378.

${ }^{72}$ Isto, 379.

${ }^{73}$ Isto, 379.

${ }^{74}$ APR, KPR II-4-a/116, Izveštaji, informacije, beleške, pisma i pisanje štampe o slučaju Milovana Đilasa. 
Reagovao je i britanski ambasador u Beogradu Ivo Malet. Prilikom prijema kod Koče Popovića zamerio je zbog antibritanskog pisanja pojedinih listova, posebno istakavši titogradsku Pobjedu. Zanimljiv je bio i Kočin odgovor: čestitao im je na obaveštenosti pošto on taj list nikada nije ni video. Zamerio je, s druge strane, britanskoj štampi u kojoj se „Slučaj Đilas“ dovodio u vezu sa povratkom Jugoslavije u Istočni blok. ${ }^{75}$

Od ambasade u Moskvi, u izveštaju Dobrivoja Vidića, možemo sagledati reagovanja u diplomatskom koru povodom slučaja. Većina je pozdravila partijsko suđenje kao „sasvim demokratski“. Sa druge strane bilo je i aluzija na "kremljovske metode“. Zanimljivo je zapažanje britanskog ambasadora koji je ironično izjavio kako se nada da se Đilas nije u Rangunu zarazio burmanskom demokratijom. Ambasador navodi i da će Moskva pozdraviti odluke Plenuma. ${ }^{76}$

Đilas, i pored partijske osude i upozorenja, nije prekinuo kontakte sa laburistima. Krajem leta 1954. u hotelu „Ekscelzior“ sastao se sa laburistom Ernestom Dejvisom. Na sastanku, održanom na Dejvisovu inicijativu, ugovoreno je objavljivanje tri Đilasova članka u laburističkim novinama Dejli Herald (Daily Herald). Do toga, međutim, nije došlo jer kako Đilas navodi: „Nisam dobio poziv, pa članci nisu ni objavljeni“ ${ }^{77}{ }^{7} \mathrm{O}$ sastanku nailazimo na samo jedan izvor - samog Đilasa, kroz memoare i stenografske beleške sa suđenja 1955. godine. U izveštajima britanske ambasade postoji samo kratak zabeleška da je Dejvis stigao u Jugoslaviju radi kratke posete, dok se o samom karakteru ili cilju posete ništa ne navodi. ${ }^{78}$ Usled toga, sa sigurnošću ne možemo tvrditi koja je bila sadržina sastanka.

Poslednja opomena, gubitak funkcija, kritika najbližih saradnika, pa i samog Tita, nisu sputali Đilasa. Decembra 1954. u Njujork tajmsu Đilas je u intervjuu Džeku Rejmondu direktno kritikovao vrh partije i ukazao na potrebu postojanja opozicione partije. Ubrzo potom podignuta je optužnica, a sudski proces je održan 24 . januara 1955. godine, zatvoren za javnost. $\mathrm{Na}$ procesu povezanost sa zapadnim socijalistima nije prošla nezapaženo, ipak Đilas je izjavio: „Ja sam svoje stanovište izgrađivao nezavisno od njih (zapadnih socijalista - N. M.), i nezavisno od njih stojim na njima“" ${ }^{79}$ Ovoga puta kazna je bila neminovna: Đilas je osuđen na kaznu zatvora od 18 meseci, uslovno na 3 godine. Za razumevanje presude ključan je spoljnopolitički kontekst. Posle Staljinove smrti otvorila se mogućnost približavanja

${ }^{75}$ D. Bekić, Jugoslavija u hladnom ratu: Odnosi sa velikim silama 1949-1955, 580.

${ }^{76}$ B. Kovačević, Đilas heroj - antiheroj: iskazi za istoriju, 393-394.

${ }^{77}$ M. Đilas, Vlast, 287; K. Nikolić, S. Cvetković, Rađanje jeretika: suđenje Milovanu Đilasu i Vladimiru Dedijeru 1955, 112.

${ }^{78}$ Yugoslavia: Political Diaries 1918-1965, Vol. 4: 1949-1965, 573.

${ }^{79}$ K. Nikolić, S. Cvetković, Rađanje jeretika: suđenje Milovanu Đilasu i Vladimiru Dedijeru 1955, 158. 
starom savezniku. Dolazak Hruščova na vlast, međutim, nije bio momentalan tako da jasni signali o mogućem izmirenju još uvek nisu dolazili. U datom trenutku ključno je bilo zadovoljiti obe strane - i Istok i Zapad. Austrijski poslanik Valter Voduk, inače tesno povezan sa sekretarom laburističke partije Morganom Filipsom, ${ }^{80}$ bio je direktan: „Jugoslavija se nalazi pred polaganjem jednog delikatnog ispita u odnosu na inostranstvo i dobro odmerena odluka prema Đilasu više će značiti nego bilo kakve jasne izjave o nepostojanju sporazumevanja sa Sovjetima". ${ }^{81}$ Usled toga uslovna presuda ispostavila se kao savršeno rešenje. Ove okolnosti nisu promakle ni samim optuženima. Posle suđenja Đilas je izjavio: „Ova presuda je sjajna i velika stvar. Ovim je podignut ugled Titu i celoj Vladi u zemlji i inostranstvu“. ${ }^{82}$ Dedijer prenosi i da je Đilas takođe izjavio: „Ovom presudom zapušili su usta nama i inostranstvu“ i „Ovakvo rešenje mogao je naći samo dalekovidi Tito" ${ }^{83}$ Značajno je napomenuti karakterisanje presude od strane britanske ambasade: u izveštaju 29. januara 1955. navodi se da je presuda i Đilasu i Dedijeru blagog karaktera (mild). Osim toga zapaženo je i njihovo povezivanje sa „izvesnim zapadnim krugovima“" ${ }^{84}$

Kao i posle partijskog suđenja očekivala se reakcija laburista. Februara iste godine na večeri ambasadora Jugoslavije u Londonu Petrića sa istaknutim laburistima: Vilfrud Burkeom, predsednik IO Laburističke partije, Morgan Filipsom, sekretarom, Sem Vatsonom, predsednikom spoljnopolitičkog komiteta i Saul Rozom, načelnikom spoljnopolitičkog komiteta, istaknuto je da je likvidacija Đilasa odstupanje od demokratije. Laburisti su izrazili žaljenje zbog prekidanja razlaza od SSSR, a kao tačku prekida videli su „Slučaj Đilas“. Zamerali su i osudu socijaldemokratskih partija na trećem plenumu. ${ }^{85}$

Radi sagledavanja reakcija zapadnih socijalista na put se otisnuo Veljko Vlahović i pri tom obišao Englesku, Belgiju i Francusku. Za temu ključni su sastanci sa Morganom Filipsom i Bevanom. Razgovor sa Filipsom Vlahović je okarakterisao kao „dosta nategnut" a sagovornika rezervisanim. Tom prilikom Filips je izrazio interesovanje za sudbinu Đilasa. Na daleko srdačniji prijem naišao je na večeri kod Bevana i Džen Li. Bevan se interesovao za Titovu reakciju na njegovo pismo i da li se eventualno zamera zbog toga.

${ }^{80}$ APR, Plenarne sednice CK KPJ 1948-1978, CK SKJ II/11, Izveštaj o putu u Englesku, Belgiju i Francusku od 25. februara do 6. marta 1954. godine - Veljko Vlahović str 5.

${ }^{81}$ APR, KPR II-4-a/116, Izveštaji, informacije, beleške, pisma i pisanje štampe o slučaju Milovana Đilasa.

${ }^{82}$ Isto.

${ }^{83}$ Isto.

${ }^{84}$ Yugoslavia: Political Diaries 1918-1965, Vol. 4: 1949-1965, 622-623.

${ }^{85}$ APR, KPR II-4-a/116, Izveštaji, informacije, beleške, pisma i pisanje štampe o slučaju Milovana Đilasa. 
Zanimljivo je da Titov odgovor, prenet preko Vlahovića, navodi da u tom interesu ne vidi neki politički momenat već da je u pitanju lično prijateljstvo Bevana i Đilasa. Bevan je izrazio saglasnost sa Đilasovim idejama o višepartijskom sistemu u Jugoslaviji, ali je i naveo da u njegovom slučaju nije u pitanju borba za vlast, već vid borbe protiv birokratije koju za Bevana oličava Kardelj. Upada u oči Bevanovo interesovanje za odjek slučaja Đilas naročito u Crnoj Gori. Na temu političkih sloboda u Jugoslaviji Vlahoviću je odgovorio: „Nema slobode u sistemu koji preko noći može da likvidira političkog čoveka i nije odraz demokratije u tome što se mase odmah slažu sa tom likvidacijom“. Na privatnom planu interesovao se za mesto stanovanja Đilasa, da li radi ili ne, kao i da li on i Dedijer mogu da šalju pisma njemu i Džen Li. Izrazio je želju da Đilasu i Dedijeru uzvrati gostoprimstvo i pitao postoji li mogućnost da oni svoj odmor provedu u Britaniji. Razgovaralo se i o primedbama Petra Stambolića na Trećem plenumu. Vlahović se potrudio da objasni „smisao" Stambolićevog izlaganja, ali je Bevan prema tome bio ravnodušan. ${ }^{86}$

Prilikom Vlahovićeve posete Francuskoj u razgovoru sa tamošnjim socijalistima primećena je aktivnost britanskih laburista u okviru Druge internacionale. Značajno je napomenuti da je predsednik Internacionale $u$ tom periodu bio Morgan Filips. ${ }^{87}$ Mnogi u Internacionali, kako se navodi, potpali su pod uticaj britanskih laburista i da pridaju značaj „Slučaju Đilas“. Naročito je zanimljiva tvrdnja da je Živko Topalović, beogradski socijaldemokrata, koji je za vreme rata bio prisni saradnik Draže Mihajlovića, ${ }^{88}$ prilikom zasedanja Internacionale nudio svim delegatima prevedene Đilasove članke. Sam Topalović od laburista dobija 200 dolara mesečno. U toku vladavine laburista, iako ostala jugoslovenska emigracija nije nailazila na njihovu podršku, Topalović je uživao zaštitu vlade uprkos uspostavljanju dobrih odnosa sa Jugoslavijom. ${ }^{89}$ Za delatnost Topalovića zalagao se i pomenuti austrijski socijalista Valter Vodak. ${ }^{90}$ Drugu potvrdu podrške Đilasu od strane Topalovića nailazimo u prenošenju vesti iz pariskog lista Komba koji, kako prenosi Politika, objavljuje pismo „Unije demokrata Srba, Hrvata i Slovenaca" u kome se pozdravljaju postupci Đilasa i Dedijera. Iza same unije, kako se navodi, stoji Topalović. ${ }^{91}$

${ }^{86}$ APR, Plenarne sednice CK KPJ 1948-1978, CK SKJ II/11, Izveštaj o putu u Englesku, Belgiju i Francusku od 25. februara do 6. marta 1954 - Veljko Vlahović, str. 1-5.

${ }^{87}$ D. Bekić, Jugoslavija u hladnom ratu: Odnosi sa velikim silama 1949-1955, 579.

${ }^{88}$ V. Dedijer, Izgubljena bitka J. V. Staljina, Sarajevo 1969, 430.

${ }^{89}$ KMJ, 836, I-2-a/140, Prijem predsednika i ministra inostranih poslova vlade Velike Britanije Entoni Idna kod Maršala Tita, Beograd, Bled 18-22. septembar 1952.

${ }^{90}$ APR, Plenarne sednice CK KPJ 1948-1978, CK SKJ II/11, Izveštaj o putu u Englesku, Belgiju i Francusku od 25. februara do 6. marta 1954. godine - Veljko Vlahović, str 5.

${ }^{91}$ Politika, 4. januar 1955, 4. 
Usledila je i zvanična reakcija. U pismu laburističke partije Titu, koji je napisao sekretar Morgan Filips, pozdravlja se presuda navodeći da su „osetili olakšanje u vezi ishoda suđenja“. Zamera se, međutim, to što je Đilas lišen ratne penzije. U pismu se navodi „da bi se mogla pronaći neka sredstva da mu omoguće da zaradi za časno življenje“. U spoljnopolitičkom kontekstu se zamera otklon ka SSSR, to jest klizanje natrag na "zle puteve kominformovskih zemalja“. ${ }^{92}$ Tito je ubrzo izašao u susret i Đilasu je vraćena penzija. Tri godine kasnije razgovor Svetozar Vukmanović-Tempo i Filips su razgovarali o sudbini Đilasa. Na pitanje odakle tolika zainteresovanost sa Đilasa, Filips odgovara „iz čisto humanitarnih razloga“. Tempo pita zašto se $u$ tom slučaju ne interesuju za sudbinu Sretena Žujovića. ${ }^{93}$. Odgovor Filipsa ilustruje spoljnopolitički kontekst čitavog slučaja: „Ali on je htio da Jugoslaviju stavi pod kontrolu Sovjetskog Saveza“. ${ }^{94}$

Slučaj Đilas privukao je pažnju inostrane štampe. „Borba“ $u$ članku Dobro je i to znati: inostrana štampa i "slučaj" Đilas - Dedijer prenosi epitete koji su pripisivani Đilasu: „stari Titov drug“, „naslednik“, „zamenik“, ,prestolonaslednik", „teoretičar Titovog režima“, "službeni teoretičar režima“, „najtalentovaniji teoretičar režima“, „marksistički filozof“, ,jugoslovenski Robespijer", "tumač osećaja velikog broja svojih sunarodnika“, „jedini komunistički vođa koji se usuđuje da misli nezavisno“, „njegova otvorenost u izjavama je legendarna“ i „on je sve probleme svoje zemlje u štampi produbljivao". 95

Slučaj Đilas, naročito karakter presude i njen kontekst u odnosu na laburiste, nije promakao ni bivšim radikalskim prvacima. Ante Radojević, ministar saobraćaja u Kraljevini SHS, pitanje penzije u iznosu od 40.000 dinara vidi kao ključan pokazatelj da sam Tito podržava Đilasa. Takođe spekuliše o prividnoj podvojenosti u Politbirou: Tito i Đilas su okrenuti ka Zapadu a Kardelj prema Istoku, sa ciljem da se „sedi na dve stolice“. Direktno navodi da je Đilas socijalista i da je povezan sa laburistima i Drugom internacionalom. Da ne bi narušio prijateljstvo sa laburistima Tito je uslovno osudio Đilasa, dao mu penziju i „pustio ga da dela“. ${ }^{96}$ Sličnu notu nailazimo u izlaganju Aleksandra Rankovića na Četvrtom plenumu: „Na Zapadu su

${ }^{92}$ APR, KPR II-4-a/116, Izveštaji, informacije, beleške, pisma i pisanje štampe o slučaju Milovana Đilasa.

${ }^{93}$ Sreten Žujović je bio istaknuti funkcioner KPJ, pripadajući samom vrhu te partije, pre, tokom i posle rata. U sukobu sa Informbiroom stao je na Staljinovu stranu usled čega je izbačen iz Politbiroa i lišen svih funkcija, ubrzo je utamničen i držan u potpunoj izolaciji. Oslobođen je 1950. godine.

${ }^{94}$ S. Vukmanović - Tempo, Revolucija koja teče: memoari, knjiga 4, Zagreb 1982, 348.

${ }^{95}$ Borba, 4. januar 1955.

${ }^{96}$ APR, KPR II-4-a/2, Informacije o aktivnosti neprijateljskih elemenata u NR Makedoniji u toku 1953. godine. 
pisali da naša reakcija na Plenumu (trećem - N. M.) potvrđuje novu orijentaciju Jugoslavije prema Istoku, a otuda, opet, trube na sav glas kako je i Treći plenum pokazao da smo duboko zagazili u zapadne vode“.97

Ubrzo je došlo je do neočekivanog obrta. Đilas je uhapšen 19. novembra 1956. zbog članka u Nju Lideru (New Leader) u kome je podržao mađarske revolucionare i kritikovao jugoslovenski stav neutralnosti, tj. de facto podrške sovjetskoj intervenciji. Ubrzo je osuđen na 3 godine strogog zatvora. Ulogu inkvizitora preuzeo je Kardelj, pošto su se Ranković i Tito nalazili na „azijskoj turneji“ ali, svakako, sa njihovim odobrenjem. Međutim, ključna je spoljnopolitička promena od uslovne presude do Mađarske revolucije. Nikita Hruščov je posetio Beograd maja -juna 1955. i tom prilikom potpisana je Beogradska deklaracija kao korak ka novom približavanju dve zemlje. U toku posete, kako se navodi, Hruščov ${ }^{98}$ je Titu poručio da je sada moguće dalje razvijanje prijateljstva jer „mi smo se oslobodili Berije a vi Đilasa"99. I zvanično, odgovornost je prebačena na njih odlukom Ruskog komiteta kojom se za pogoršanje odnosa upravo oni krive. ${ }^{100}$ Iste, 1955. godine počinje proces obustave vojne pomoći sa Zapada. Još na početku dobijanja pomoći Tito je istakao izvesnu opasnost zbog primanja te pomoći u kontekstu političke nezavisnosti zemlje. Sada je prevladalo mišljenje da pomoć donosi više štete nego koristi. ${ }^{101}$ Paradoksalno, slučaj Đilas je na specifičan način doprineo obnovi odnosa Moskve i Beograda. ${ }^{102}$

Karakter odnosa između Đilasa i britanskih laburista bio je intenzivan i prijateljski. Dok su sa Morganom Filipsom oni su imali dominantno političku notu, sa Bevanom i Dženi Li pored političke imali su i izraženu notu prijateljstva: glavni agitator za oslobađanje, pravičnu presudu i dodelu penzije Đilasu, kao i Dedijeru, bio je upravo Bevan, ponekad i na sopstvenu štetu.

Postavlja se pitanja interesa laburista u čitavom slučaju. S jedne strane postoji širenje uticaja preko Đilasovih članaka u Drugoj internacionali, što

97 APR, Plenarne sednice CK KPJ 1948-1978, CK SKJ II/11, Izlaganje Edvarda Kardelja na Četvrtom plenumu.

${ }^{98}$ U literaturi se može naći da je ovu rečenicu, ili uslov, prvi izgovorio Molotov: D. Bekić, Jugoslavija u hladnom ratu: Odnosi sa velikim silama 1949-1955, 582.

${ }_{99}$ Dž. Ridli, Tito, 309. Navedeno prema: K. Nikolić, S. Cvetković, Rađanje jeretika: suđenje Milovanu Đilasu i Vladimiru Dedijeru 1955, 58; V. Dedijer, Veliki buntovnik Milovan Đilas: prilozi za biografiju, 421.

${ }^{100}$ A. Edemskii, The role of Milovan Đilas in Soviet-Yugoslav relations, 1944-1954, The Balkans in the Cold War: Balkan Federations, Cominform, Yugoslav-Soviet conflict, 216.

${ }^{101}$ I. Laković, Zapadna vojna pomoć Jugoslaviji: 1951-1958, 222-223.

102 A. Edemskii, The role of Milovan Đilas in Soviet-Yugoslav relations, 1944-1954, The Balkans in the Cold War: Balkan Federations, Cominform, Yugoslav-Soviet conflict, 185. 
može biti puko korišćenje datih okolnosti ne bi li se laburističko viđenje socijalizma proširilo. S druge strane čitav slučaj predstavljao je pokušaj približavanja sa Jugoslavijom na idejnom planu, ne bi li definitivno uplivala u zapadne vode. U Đilasu su videli faktor koji može prevagnuti u korist drugih ideja.

Mogućnost da se sa promenom ideja promeni i vođa Jugoslavije javlja se i u izvorima. Ipak, to su samo razbacani i oskudni fragmenti, dok ostaje činjenica da „đilasovštvina“ nikada nije zaživela. Uostalom, srazmerno mali broj ljudi je izbačen iz partije povodom čitavog slučaja. ${ }^{103}$ Sam Đilas, iako je imao priliku, nije se stavio na čelo opozicije, niti je ni na koji konkretan način podsticao njeno dalje delovanje.

Prisutna je i teza o „savršenom disidentu“ ili pak „o sedenju na dve stolice“. Posle Staljinove smrti 1953. godine Tito je veoma oprezno sagledavao događaje kako u Moskvi tako i na Zapadu. Sa Zapada, kao što je Atlijev govor i pokazao, dolazili su zahtevi za promenu karaktera režima radi dalje saradnje i produbljivanja odnosa. Ako bliže sagledamo: Staljin je umro 5. marta 1953, Atlijeve primedbe o državnom uređenju Jugoslavije iznete su 18. avgusta, a prvi članak je izašao 11. oktobra iste godine. Đilasovi članci su došli u savršeno vreme, naizgled pružajući sliku mogućnosti promene $u$ samoj Jugoslaviji. Sama činjenica da je Đilasu omogućeno da „nastavi da dela" i da mu je dodeljena penzija govore u prilog teza o koristi čitavog slučaja. Ne treba zaboraviti ni na dugogodišnje prijateljstvo Tita i Đilasa. Upravo u kompleksom periodu 1953-1955. „Slučaj Đilas“ omogućavao je Titu, uz ostale faktore, da balansira između dva bloka čekajući definitivan signal iz Moskve.

Paradoksalno (ili ne?) i pri pomirenju Đilasova delatnost itekako je išla na ruku Titu. Člankom u Nju Lideru omogućeno je novo suđenje i sada definitivno utamničenje disidenta.

Službe SAD, prepoznajući potencijal idejnog „Trojanskog konja“, u komunističkom svetu izlaze u prvi plan, naročito posle objavljivanja Nove klase. U tim godinama glas laburista, pre svega Bevana, za oslobađanje Đilasa zataškan je hladnoratovskom tenzijom. Prijateljstvo sa Bevanom, međutim, i dalje je bilo značajno - novim okolnostima upravo će on biti najverniji zaštitnik Milovana Đilasa.

${ }^{103}$ Ukupno je izbačena 21 osoba, a kažnjeno je 6. Najviše lica bilo je iz Crne Gore: 4 izbačena i 3 kažnjena. APR, Plenarne sednice CK KPJ 1948-1978, CK SKJ II/11, Pripreme za Četvrti plenum. 
Nikola Mijatov

MILOVAN DJILAS AND THE BRITISH LABOURISTS 1950-1955

\section{Summary}

The relationship between the Milovan Djilas and the British Labourists, are important concerning his later dissident activities. This article reviles the origins and character of these relations, in period when Djilas was in the political power and after 1954 in the first phase of his dissident status. The establishment of the first contacts, exchanging the ideas and developing of personal relationship will bring the harsh political and personal consequences. Djilas was arrested after his article in the New Leader magazine in 1956 where he criticized the Yugoslav standpoint on the events in Hungary. This article is written upon the archival research as well on the wide literature. 